\title{
BIOAVAILABILITY OF IRON FROM FOXTAIL MILLET AND SORGHUM MILLET RECIPES
}

\author{
M. MOUNIKA, K. UMA DEVI \& S. SUCHARITHA DEVI \\ Department of Foods and Nutrition, Post Graduate and Research Centre
}

Professor Jayashankar, Telangana State Agricultural University

Rajendranagar, Hyderabad

\begin{abstract}
The present study entitled "Bioavailability of iron from foxtail millet and sorghum based recipes" was conducted on four millet preparations namely dosa, idly, roti and rice, using two millets namely foxtail millet, sorghum. The iron content of millets was $2.69 \mathrm{~g}, 4.0 \mathrm{~g}$, in foxtail millet, sorghum. Bio available iron in millet dosas was least with $1.71 \mathrm{mg}$ in foxtail millet dosa and highest with 2.85 in sorghum millet dosa with and $2.03 \mathrm{mg}$ from rice dosa. In millet idles maximum $2.22 \mathrm{mg}$ in foxtail millet idly and $0.125 \mathrm{mg}$ in control rice idli. In millet rotis maximum was found in sorghum millet roti with $2.158 \mathrm{mg}$ compared to control wheat roti with $0.25 \mathrm{mg}$. Available iron in millet meals was maximum in foxtail millet meal with 2.03mg. Compared to control rice meal, foxtail millet and sorghum millet meal had higher available iron. Significant difference was found in the bio available iron from any two millets and between millet meals and rice meal $(p<0.05)$.
\end{abstract}

KEYWORDS: Millets, Dosa, Idly, Roti and Meal \& Iron Availability

Received: Jul 05, 2017; Accepted: Jul 26, 2017; Published: Aug 11, 2017; Paper Id.: IJASRAUG201792

\section{INTRODUCTION}

The name millet is applied to numerous small seeded grasses which originated in Asia or Africa. Millets include five Genera, Panicum, Setaria, Echinochloa, Pennisetum, and Paspalum. The most important cultivated species of millets are foxtail (Setaria italica), pearl or cattail millet (Pennisetum glaucum), proso (Panicum miliaceum), finger millet (Eleusine coracana), little millet, and teff millet (Eragrostis tef).Various millets grown in India are finger millet (Eleusine coracana), and little millet (Panicum milliare) and sorghum (Sorghum vulgare). The bioavailability of iron in a meal is the result of several known and unknown dietary factors. The absorption of these two kinds of iron is influenced differently by dietary factors. Heine iron forms a relatively minor part of iron intake. Even in diets with high meat content it accounts for only 10-15\% of the total iron intake.

\section{MATERIALS AND METHODS}

Sorghum and foxtail millets were procured from Grameenmall Foundation this is one of NGO for promoting former to grow cultivate the millets, Hyderabad.

In this study were selected four millet recipes, millet idly, millet roti and millet dosa and millet meal, each recipe was prepared with each different millet. Millet meal was cooked as normal rice meal. Row millet: 50g and double quantity of water. Soak the millet for $1 / 2$ for all other millet and one hour (for sorghum ) and wash the millet two times and cook $5-7$ minutes. 
Millet idly made with millet rawa (semolina) and black gram dhal (2:1), black gram was soaked for 2-3 hour and grinded the black gram and mixed the washed millet rawa and added little bit salt into batter fermented for overnight and made idly with that batter followed steaming method. Idles were increase double quantity volume, finger millet increased little volume compared with all other millet Idle.

Millet dosa made with whole millet and black gram dhal (2:1) were soaked 2 hours separately and grind the millet to fine batter and again grinded black gram separately, added little bit salt and mixed those in one vessel kept for fermentation overnight the dosa made on non stick pan with used little oil, uniformly spread batter on pan. $50 \mathrm{~g}$ millet and 25 g black gram batter gave 2 dosa.

Millet roti was prepared with $50 \mathrm{~g}$ millet flour and water for roti making hot water used and didn't use chapathi maker, used only fingers, $50 \mathrm{~g}$ flour gave 1 roti.

Raw grains of the selected millets were analysed for the proximate nutrients and mineral composition from the edible portion of each grain. Sorghum was edible without dehulling, whereas, foxtail millet, dehulled to make that edible. The selected millets were analysed for moisture, protein, fat, dietary fibre, and ash by standard chemical analysis and carbohydrate was calculated by difference method. Iron, calcium and zinc were the minerals analysed. The nutrient composition of the analysed millets is given in table. 1

Table 1: Nutrient Composition of Millets and Cereals

\begin{tabular}{|l|c|c|c|c|c|c|c|c|c|c|}
\hline \multicolumn{1}{|c}{ Millets } & $\begin{array}{c}\text { Moisture } \\
(\mathbf{g})\end{array}$ & $\begin{array}{c}\text { Protein } \\
(\mathbf{g})\end{array}$ & $\begin{array}{c}\text { Fat } \\
(\mathbf{g})\end{array}$ & $\begin{array}{c}\text { Energy } \\
(\text { Kcal) }\end{array}$ & $\begin{array}{c}\text { Ash } \\
(\mathbf{g})\end{array}$ & $\begin{array}{c}\text { Dietary } \\
\text { fibre(g) }\end{array}$ & $\begin{array}{c}\text { Carbohydrate } \\
(\mathbf{g})\end{array}$ & $\begin{array}{c}\text { Iron } \\
(\mathbf{m g})\end{array}$ & $\begin{array}{c}\text { Zinc } \\
(\mathbf{m g})\end{array}$ & $\begin{array}{c}\text { Calcium } \\
(\mathbf{m g})\end{array}$ \\
\hline Foxtail millet & 9.1 & 11.9 & 4.1 & 351 & 3.00 & 11.24 & 61.4 & 2.69 & 2.85 & 23.3 \\
\hline Sorghum & 11.6 & 9.6 & 1.9 & 349 & 1.80 & 9.7 & 65.6 & 4.0 & 2.10 & 24.1 \\
\hline Rice & 13.2 & 6.1 & 0.6 & 347 & 0.8 & 3.2 & 77.0 & 0.5 & 1.2 & 9.6 \\
\hline Wheat & 12.0 & 11.2 & 1.2 & 339 & 2.5 & 10.1 & 64.9 & 4.5 & 2.2 & 46 \\
\hline
\end{tabular}

The moisture content of sorghum millet with $11.6 \mathrm{~g} / 100 \mathrm{~g}$, foxtail millet with $9.1 \mathrm{~g}$ and rice had $13.2 \mathrm{~g}$. Compared with rice sorghum and foxtail millets have lower content of moisture. Fat content foxtail millet $4.1 \mathrm{~g}$ and sorghum $1.9 \mathrm{~g}$ had and of fat respectively. The fat content of almost all millets were higher than that of common cereals like rice and wheat. Fat in millets its helps in food softening and matrix, and its give daily requirement of fat along with minerals and dietary fibre for adults and its gives $1 / 4$ th requirement for children, give essential fatty acids like palmitic acid and linelonic acid those important for heart health.

\section{Protein}

Among different millets 11.9 in foxtail millet had the highest content of protein and sorghum had millet had the lowest protein content of $7.0 \mathrm{~g} / 100 \mathrm{~g}$.

The higher protein content of millets on par with cereals along with equal energy value makes millets a good substitute for the refined rice or gluten rich wheat, both of which are not recommended for some population with metabolic disorders or those who suffer from gluten enteropathy respectively. In the face of increasing population and stagnant wheat and rice productions, millets are good for those types of diseases and millets can be a promising alternative in solving the problem of food insecurity and malnutrition. Nowadays children face constipation problems due to excess eating of refined food through millets based foods reduce that problems and give the minerals and vitamins.

Kalinova and Moudry, 2006 reported that protein content of Korean foxtail millet and proso millet significantly 
elevated plasma adiponectin and HDL cholesterol levels and caused major decreases in insulin levels relative to a casein diet in type 2 diabetic mice. Furthermore, proso millet also improved glycemic responses and plasma levels.

\section{Dietary Fibre}

Among millets, finger millet had highest content of dietary fibre and other millets decreasing order of dietary fibre, foxtail millet $11.4 \mathrm{~g} / 100 \mathrm{~g}$, sorghum $9.7 \mathrm{~g} / 100 \mathrm{~g}$ and $3.2 \mathrm{~g} / 100 \mathrm{~g}$ in rice, when compared to rice millets have high content of dietary fibre. Though foxtail millet was dehulled to make it edible, the fibre content was high compared to sorghum.

Consumption of dietary fibre that was viscous lowers blood glucose levels and helps to maintain it and also helps to treat cardiovascular and type II diabetes. Fibres are incompletely or slowly fermented by microflora in the colon promotes normal laxation which prevents constipation, diverticulosis and diverticulitis.

The health benefits associated with high fibre foods are delayed nutrient absorption, increased faecal bulk, lowering of blood lipids, prevention of colon cancer, barrier to digestion, mobility of intestinal contents, increased faecal transit time and fermentability characteristics (Tharanathan and Mahadevamma, 2003).

\section{Ash Content}

Ash content of foxtail millet $3.0 \mathrm{~g} / 100 \mathrm{~g}$, sorghum $1.8 \mathrm{~g} / 100 \mathrm{~g}$ and rice with $0.8 \mathrm{~g}$, when compared to rice millets have high content of ash content.

Pushparaj and Urooj (2011) reported low content in sorghum 1.8g/100g, other millets finger millet, pearl, foxtail, sorghum, little $1.13 \mathrm{~g} / 100 \mathrm{~g}, 2.2 \mathrm{~g} / 100 \mathrm{~g}, 3.0 \mathrm{~g} / 100 \mathrm{~g}, 1.8 \mathrm{~g} / 100 \mathrm{~g}$ and $2.8 \mathrm{~g} / 100 \mathrm{~g}$ respectively.

\section{Mineral Composition of Millets}

Iron content of millets $4.0 \mathrm{mg}$ in sorghum and $2.6 \mathrm{mg}$ in foxtail millet Iron content of wheat and rice was 4.5 and $0.5 \mathrm{~g}$. Zinc content in $2.8 \mathrm{mg}$ in foxtail millet, and $2.10 \mathrm{mg}$ in sorghum per $100 \mathrm{~g}$ of grain. In rice the zinc content was $1.2 \mathrm{mg} / 100 \mathrm{~g}$ which was lower than other millets where as in wheat was observed to be $2.2 \mathrm{mg} / 100 \mathrm{~g}$.Calcium content of $43.6 \mathrm{mg}$ in foxtail millet and $23.3 \mathrm{mg}$ in sorghum, rice was $9.6 \mathrm{mg}$ which was least compared millets.

Hema et al. (2011) reported that iron was more localized in the peripheral region than in the endosperm as evidenced by the fact that decortication for shorter duration removed 46 to $62 \%$ of this mineral. Though finger millet had lower protein content, than other millets and poor when compared to other cereals, it has an extremely high calcium and manganese content, but other minerals and trace elements are comparable to that of sorghum.

Hama et al. (2011) reported that iron was more localized in the peripheral region than in the endosperm as evidenced by the fact that decortications for shorter duration removed $46 \%$ to $62 \%$ of this mineral.

\section{Nutrient Composition of Millet Recipes}

In this study four recipes were prepared with millets and calculated nutrient content are protein, dietary fibre and energy and TWO WAY ANOVA done for influence on iron bioavailability in millet recipes.

\section{Protein}

Among the dosa preparations foxtail millet dosa had highest protein content of $26.5 \mathrm{~g}, 17.7 \mathrm{~g}$ in sorghum dosa. When compared to $15.3 \mathrm{~g}$ protein of rice dosa, foxtail and sorghum dosas had high protein content. Dosa made of foxtail 
millet and sorghum millets was superior in its protein content composed to traditional rice based dosa. The protein content of foxtail millet idli was $29.8 \mathrm{~g}$ and it was highest compared to all other millet idlis and sorghum idli with $19.6 \mathrm{~g}$, The traditional idli recipe made from blackgramdal and idli rawa par boiled rice milled into semolina had 21.5gprotein.

Idli made of foxtail millet had higher protein than traditional rice based idly. While sorghum idly had lower protein compared to rice, while the rice idlis, millet based idlis had lower protein compared to rice. Meal protein content in millet meal 11.7 in sorghum meal, $14.7 \mathrm{~g}$ in foxtail meal. Normal traditional rice meal had the least protein content of $5.4 \mathrm{~g} / 100 \mathrm{~g}$ compared to any millet meal. The boiled millets just like Oryza sativa could be served as millet rice (meal) and all millet rice samples were found to have higher protein content compared to Oryza rice. The protein content of sorghum meal rice was almost double that of normal rice and protein of foxtail millet rice was nearly thrice that of rice protein. Protein content of millet rotis $11.4 \mathrm{~g}$ in sorghum roti, $14.7 \mathrm{~g}$ foxtail millet roti and when compared to millet roties, wheat roti had the least protein content. When the protein content of rotis was, compared with the protein of control wheat roti, two millet rotis had higher protein content.

Among the two millets foxtail millet had the highest amount of protein in all four recipes i.e., rice, roti, idli and dosa made of not only millets but also of rice and wheat.

Among the four preparations dosa, idly, roti and meal prepared from millets had highest mean protein. Millet and black gram dhal combination recipes idly and dosa had high amount of protein.

\section{Dietary Fibre}

The dietary fibre content in millet dosas followed the increasing order from sorghum dosa with $6.8 \mathrm{~g}$, foxtail millet dosa with 20.2g. Traditional rice based dosa had $7.5 \mathrm{~g}$ dietary fibre, which was lower than all millet dosas except sorghum dosa. Foxtail millet dosa and proso millet dosa had closer dietary fibre values and finger millet dosa and pearl millet dosa had similar values of dietary fibre content. Rice idly had the least dietary fibre of $7.6 \mathrm{~g}$ compared to millet idlis. Dietary fibre was highest in foxtail millet idli with $22.8 \mathrm{~g}$, finger millet idli with $20.8 \mathrm{~g}$ and least in sorghum idli with $11.8 \mathrm{~g}$ per $100 \mathrm{~g}$.

Dietary fibre of control wheat roti was $3.8 \mathrm{~g}$, which was the least of all roties. The dietary fibre content of millet roties was followed by $13.2 \mathrm{~g}$ in finger millet roti and in the increasing order of roties, $13.7 \mathrm{~g}$ in pearl millet roti, $14.0 \mathrm{~g}$ in foxtail millet roti, $5.7 \mathrm{gin}$ sorghum roti, $10.7 \mathrm{~g}$ in proso roti and $8.7 \mathrm{~g} / 100 \mathrm{~g}$ in little millet roti.

The dietary fibre content was slightly increased in highest in foxtail millet idly, proso millet dosa and all other millet products have low content of dietary fibre. Low dietary fibre content in rice products, sorghum meal and all other millet products had lower than foxtail and proso millet recipes.

\section{TOTAL IRON CONTENT, AVAILABILITY OF IRON AND BIOAVAILABLE IRON FROM MILLET PREPARATIONS}

Total iron content and in vitro available iron were analysed from dosa, idli, meal and roti preparations made from the selected 2 varieties of millet along with control rice and wheat preparations and the results are given in table 1. 
Table 2: Iron, Bio Available Iron and \% Available Iron Content of Millet Rice (wheat) Recipes

\begin{tabular}{|c|c|c|c|c|c|c|c|c|c|c|c|c|c|}
\hline & \multirow[t]{2}{*}{ Millets/control } & \multicolumn{3}{|c|}{ Dosa } & \multicolumn{3}{|c|}{ Idly } & \multicolumn{3}{|c|}{ Roti } & \multicolumn{3}{|c|}{ Ileal } \\
\hline & & $\begin{array}{l}\text { Total } \\
\text { iron (mg) }\end{array}$ & $\begin{array}{l}\text { Available } \\
\text { iron (mg) }\end{array}$ & $\begin{array}{l}\text { Available } \\
\text { iron (\%) }\end{array}$ & $\begin{array}{l}\text { Total } \\
\text { Iron (mg }\end{array}$ & $\begin{array}{l}\text { Available } \\
\text { iron (mg) }\end{array}$ & $\begin{array}{l}\text { Available } \\
\text { iron (\%) }\end{array}$ & $\begin{array}{l}\text { Total } \\
\text { iron (mg) }\end{array}$ & $\begin{array}{l}\text { Available } \\
\text { iron (mg) }\end{array}$ & \begin{tabular}{|l} 
Available \\
iron $(\%)$
\end{tabular} & \begin{tabular}{|l|l} 
Total \\
iron (mg)
\end{tabular} & $\begin{array}{l}\text { Available } \\
\text { iron (mg) }\end{array}$ & $\begin{array}{l}\text { Available } \\
\text { iron }(\%)\end{array}$ \\
\hline 2 & Control & $7.93^{3}$ & $2.03^{\circ}$ & $25.6^{\circ}$ & $1.88^{\circ}$ & $0.125^{\circ}$ & 6.596 & $4.8^{\mathrm{a}}$ & $0.25^{\mathrm{a}}$ & $5.2^{\mathrm{a}}$ & $3.87^{7}$ & $0.32^{\circ}$ & $8.2^{6}$ \\
\hline 3 & Foxtail millet & $4.10^{6}$ & $1.71^{6}$ & $41.8^{\circ}$ & $3.6^{\mathrm{a}}$ & $2.22^{\mathrm{3}}$ & $58.8^{3}$ & $3.41^{b}$ & $0.051^{6}$ & $1.40^{\circ}$ & $3.9 \mathrm{a}$ & $2.03^{3}$ & $52.0^{3}$ \\
\hline 4 & Sorghum millet & $4.99^{6}$ & $2.85^{a}$ & $57.1^{1 \mathrm{a}}$ & $3.47^{\circ}$ & $0.64^{b}$ & $18.4^{\circ}$ & 3.356 & $0.072^{b}$ & $2.14^{b}$ & $3.277^{\circ}$ & $0.34^{\circ}$ & $10.5^{b}$ \\
\hline
\end{tabular}

Foxtail millet dosa had $4.1 \mathrm{mg}$, which was the highest among the all foxtail millet preparations, followed by $3.9 \mathrm{mg}$ in meal, 3.6mg in idli and $3.41 \mathrm{mg}$ in roti, with significant difference between the recipes ( $\mathrm{p}<0.01)$ though the total iron was good in all the preparations, bio available iron content reduced in all foxtail millet recipes. The in vitro available iron seems to be very low in foxtail millet roti compared to other recipes.

Percent available iron was highest in foxtail millet idly at $58.8 \%$ against $52.07 \%$ in meal, $41.8 \%$ in dosa and $1.40 \%$ in roti significant difference $(\mathrm{p}<0.1)$ between the recipes of foxtail millet. This indicated the suitability of simple processing techniques for improvement of availability of nutrients from foxtail millet. Among all foxtail millet recipes idli, meal and dosa could be taken as best recipes for bio available.

\section{Iron Availability from Sorghum Preparations}

Total iron, bio available iron and percent availability of iron of sorghum preparations are given in table 4.4. The total iron was good in all sorghum preparations.

Sorghum dosa had $4.99 \mathrm{mg}$ of iron, which was highest, followed by 3.47 in idli, $3.35 \mathrm{mg}$ in roti and $3.27 \mathrm{mg}$ in meal. From the total iron bio available iron content reduced drastically to 0.07 in roti, $0.346 \mathrm{mg}$ in meal and $0.64 \mathrm{mg}$ in idli with and dosa with 2.85 with significant difference $(p<0.05)$ but not between roti and meal. The bio availability of iron seems to be very low in moist treated sorghum compared to dry heat or roasted sorghum preparations.

Percent available iron was highest in sorghum $57.1 \%$ in dosa, against $18.4 \%$ in idly, $10.58 \%$ in meal and $2.149 \%$ in roti with significant difference with each other at $5 \%$ level.

Iron contamination from equipment during milling has been reported and is attributed to frictional wear and tear of the moving mill parts, with consequent elevation of iron in flours but in this study whole grain was used so phytates content was high and iron availability was less in rotis. Significant reduction in total phenols and flavonoids after soaking sorghum grains for $20 \mathrm{~h}$ in water was also observed (Afify et al., 2011). The combination of treatments like germination and steaming was not so effective either in decreasing the polyphenols or the flavonoids (1.9\%and 15.14\%), as compared to the other treatments. This study shows that treating the grain components separately is more beneficial than whole grain treatments in decreasing the inhibitory factors.

\section{Iron Availability from Control/Rice or Wheat Preparations}

The total iron, available iron and percent availability of iron of rice preparations like dosa, idli and meal and wheat preparation roti are given in table 1 . Total iron content was $7.9 \mathrm{mg}$ in rice dosa, which was highest, followed by $4.8 \mathrm{mg}$ in roti, $3.8 \mathrm{mg}$ in meal and $1.8 \mathrm{mg}$ in idli, with significant difference between preparations $(\mathrm{p}<0.05)$ bioavailable iron was $2.037 \mathrm{mg}$ in dosa, $0.32 \mathrm{mg}$ in meal, $0.250 \mathrm{mg}$ in roti and $0.124 \mathrm{mg}$ in idli with significant difference $(\mathrm{p}<0.05)$ between each other. 
Percent available iron was least in roti at 5.2\% against meal at $8.2 \%$, idly at $6.59 \%$ and dosa at $25.6 \%$ with significant difference between each other. Hemaltha et al., 2006 reported $23.05 \%$ availability of iron from rice and black gram combination idli. Though rice based dosa had near values with $30 \%$ of available iron.

Iron bioavailability is low due to high levels of dietary phytates and fibres in millets. Processing techniques such as soaking, germination, fermentation and further cooking have been found to reduce significantly the levels of phytates and tannins by exogenous and endogenous enzymes formed during processing. Heat processing as in dosa frying, roti roasting and boiling for meal preparation softens the food matrix, releases bound iron from protein and facilitates and availability.

The digestibility and hence absorption of micronutrients such as iron is improved upon heat processing, which results in softening of the food matrix, and release of protein -bound iron, thus facilitating its absorption.

\section{CONCLUSIONS}

Millet recipes like dosa, idly, roti and meals were made with millets in foxtail millet recipes were dosa and idly have high percent of available iron compared with other millet and rice recipes. On fermentation available iron was increased and baking and boling method didnt improve the iron available in roties and meals, compared between four recipes, dosa and idly have high available iron. In other aspect protein had negatively effect on iron available in dosa and dietary fiber had negative effect on other recipes.

\section{REFERENCES}

1. Afify, A.E.M.R., Hossam, S., Beltagi, S.E., Samiha, M., Salam, A.E and Omran, A.A 2011. Bioavailability of iron, zinc, phytate and phytase activity during soaking and germination of white sorghum varieties. PLoS ONE. 6 (10): 25512-25516.

2. Hama, F., Icard,Vernie, R., Guyot, J.P., Picq, C.J., Diawana,B., Mouquect and Rivier, C. 2011.Evoluation of the micro and macro nutrient composition of pearl millet and white sorghum during in field versus laboratory decortication. Journal of Cereal Science.54: 425-433.

3. Hemalatha. 2006. Studies on the bioavailability of micronutrient from Indian food. Ph.D Thesis. University of Mysore, Mysore.

4. Lestienne, I., Besancon, P., Caporiccio, B., Pelerin, L.V., Treche, S. 2005. Iron and zinc in vitro availability in pearl millet flours (Pennisetumglaucum) with varying phytate, tannin, and fiber contents. J. Agric. Food Chem. 53: 3240-3247.

5. Narasinga Rao, B.S. 2007.Bioavailability of dietary iron and iron deficiency anaemia. NFI Bulletin.

6. Narasinga Rao, B.S. and Prabhavathi, T. 1978. An Invitro method for predicting the bioavailability of iron foods. Am. J. Clin.Nutrition. 31:169-175.

7. Pushparaj, F. S and Urooj, A. 2011. Influence of processing on dietary fibre, tannin and in vitro protein digestibility of pearl millet. Food and Nutrition Sciences. 2(8): 895-900.

8. Tharanathan, R. N and Mahadevamma, S. 2003.Grain legumes a boon to human nutrition. Trends in Food Science Technolgy. 14(12): 507-518. 